\title{
Penanganan Degradasi Dasar Sungai Krueng Jantho dengan Perencanaan Groundsill
}

\author{
Marini Bravikawati ${ }^{1}$ Eldina Fatimah $^{2}$ Ziana $^{3}$ \\ ${ }^{1}$ Mahasiswa, Jurusan Teknik Sipil, Universitas Syiah Kuala, Banda Aceh 23111, Indonesia \\ 2,3 Jurusan Teknik Sipil, Universitas Syiah Kuala, Banda Aceh 23111, Indonesia. \\ Email: marinibrafikawati@gmail.com
}

\begin{abstract}
Krueng Jantho river has an important role in the utilization of water resources, watershed conservation, and control of water damage. Dredging of river material has resulted in damage to the ecological factors of the Krueng Jantho river, specifically the degradation of the riverbed which can trigger the collapse of river banks and bridge pillars. The location under review is located in Alue Gintung Village, Seulimuem District, Aceh Besar Regency. Data and maps collected are watershed maps, river discharge data from the Krueng Aceh water level measurement post (AWLR), and topographical and river cross-section data. The method of calculating the generation of discharge data is used the Markov Chain method, the analysis of flood discharge plans using the Pearson Log type III distribution method, and the groundsill building planning for river bottom management and security. The groundsill building for the 25 yearly discharge is planned to be $80.00 \mathrm{~m}$ wide, groundsill 1,00 $\mathrm{m}$ high and $4.00 \mathrm{~m}$ thick groundsill lighthouse.
\end{abstract}

Keywords : river, degradation, arrangement, groundsill.

\begin{abstract}
Abstrak
Sungai Krueng Jantho mempunyai peranan penting dalam pemanfaatan sumber daya air, konservasi DAS, dan pengendalian daya rusak air. Pengerukan material sungai telah berdampak pada rusaknya faktor ekologi sungai Krueng Jantho, khususnya degradasi dasar sungai yang dapat memicu runtuhnya tebing sungai dan pilar jembatan. Tujuan studi ini adalah untuk mengkaji dan merencanakan bangunan pengaturan sungai Krueng Jantho. Lokasi yang ditinjau terletak di Desa Alue Gintung Kecamatan Seulimuem Kabupaten Aceh Besar. Data dan peta yang dikumpulkan adalah peta daerah aliran sungai, data debit sungai dari pos pengukuran muka air (AWLR) Krueng Aceh, dan data topografi serta penampang sungai. Metode perhitungan pembangkitan data debit digunakan metode Markov Chain, analisis debit banjir rencana menggunakan metode distribusi Log Pearson tipe III, dan perencanaan bangunan groundsill untuk pengaturan dan pengamanan dasar sungai. Bangunan groundsill untuk debit 25 tahunan direncanakan dengan lebar groundsill 80,00 m, tinggi groundsill $1,00 \mathrm{~m}$ dan tebal mercu groundsill $4,00 \mathrm{~m}$.
\end{abstract}

Kata kunci : sungai, degradasi, pengaturan, groundsill.

\section{Pendahuluan}

Sungai Krueng Jantho, yang terletak di bagian hulu DAS (Daerah Aliran Sungai), merupakan salah satu anak sungai Krueng Aceh yang mempunyai peranan penting dalam kegiatan pemanfaatan sumber daya air, konservasi DAS, dan juga pengendalian daya rusak air.

Meningkatnya pendayagunaan sumber daya air terutama dalam menunjang pembangunan infrastruktur, telah berdampak terhadap kondisi dan sumber daya sungai Krueng Jantho, terutama berupa pengerukan material sungai. Aktivitas pengerukan material sungai yang dilakukan telah memberikan dampak terhadap DAS Krueng Aceh, khususnya Krueng Jantho. Salah satu dampak yang ditimbulkan oleh kegiatan ini adalah degradasi dasar sungai Krueng Jantho yang dapat memicu runtuhnya tebing sungai dan pilar jembatan, karena terjadinya perubahan morfologi sungai dan meningkatnya kecepatan aliran sungai.
Penulisan tugas akhir ini bertujuan untuk mengkaji dan merencanakan bangunan perbaikan sungai dan pengamanan tebing sungai Krueng Jantho. Lokasi yang ditinjau terletak di Desa Alue Gintung Kecamatan Seulimuem Kabupaten Aceh Besar. Lokasi ini dipilih dikarenakan pada bagian sungai tersebut terdapat Jembatan Alue Gintung, dimana di bagian hulu dan hilir jembatan adanya kegiatan pengambilan material sungai berupa pasir dan kerikil yang cukup massif. Lokasi tersebut juga merupakan daerah yang rawan terjadinya gerusan pada sungai apabila terjadi debit yang cukup besar.

Alternatif upaya penanganan yang direncanakan dalam studi ini adalah berupa pembuatan bangunan ambang (groundsill) untuk pengamanan dasar sungai di hulu dan hilir jembatan untuk pengamanan tebing dan sempadan sungai.

Metodologi dan ruang lingkup studi ini adalah pengumpulan data untuk perencanaan pengaturan sungai, yang meliputi: peta daerah aliran sungai, data debit sungai dari pos pengukuran muka air (AWLR) 
terdekat serta data topografi dan penampang sungai. Setelah dilakukan pengumpulan data, dilakukan pengolahan data dan analisis hidrologi yaitu perhitungan debit banjir rencana. Langkah selanjutnya adalah perhitungan dan perencanaan pengamanan dasar sungai berupa groundsill.

Bangunan groundsill direncanakan sebanyak lima unit yang terbuat dari konstruksi pasangan bronjong dan pondasi pasangan batu. Bangunan groundsill direncanakan dengan lebar dasar melintang sungai $80,00 \mathrm{~m}$, tinggi groundsill $1,00 \mathrm{~m}$ dan lebar groundsill 4,00 m. Rerata kemiringan eksisting dasar sungai di lokasi perencanaan adalah 0,0033, dan setelah adanya groundsill kemiringan dasar sungai direncanakan menjadi lebih landai, yaitu 0,0005. Perubahan kemiringan dasar sungai ini diharapkan berdampak baik terhadap morfologi dasar sungai, dapat menghindari terjadinya degradasi dasar sungai, dan dapat melindungi pondasi jembatan di lokasi tersebut.

\section{Tinjauan pustaka}

\section{Pembangkitan Data Debit}

Menurut Soewarno [1], rangkaian data deret berkala dengan pertambahan waktu bulanan tidak dapat dipandang sebagai variable bebas, misal, debit bulan ini, besarnya sangat tergantung dari debit bulan lalu, bahkan mungkin bulan-bulan sebelumnya, oleh karena itu untuk membangkitkan data deret berkala buatan data bulanan sebaiknya digunakan proses Markov.

Proses Markov menggunakan model autoregresif tahunan. Model yang paling sederhana adalah Markov-Chain. Untuk mendapatkan deret berkala buatan dengan pertambahan waktu bulanan digunakan persamaan:

$X_{i, j}=\bar{X}_{j}+\left\lceil\mathrm{j} \frac{\mathrm{s}_{\mathrm{j}}}{\mathrm{s}_{\mathrm{j}-1}}\left(\mathrm{X}_{\mathrm{i}-1, \mathrm{j}-1}-\overline{\mathrm{X}_{\mathrm{j}-1}}\right)+\mathrm{t}_{\mathrm{i}, \mathrm{j}}\left(\mathrm{S}_{\mathrm{j}}\right)\left(1-\left\lceil\mathrm{j}^{2}\right)^{1 / 2} \ldots 1\right)\right.$

Subskrip j menunjukkan jumlah bulan, sedangkan subskrip i menunjukkan jumlah tahun. Nilai $\lceil\mathrm{j}$ adalah koefisien korelasi serial antara $\mathrm{Xj}$ dan $\mathrm{Xj}-1$. Nilai $\mathrm{Sj}$ dan $\mathrm{Sj}-1$ adalah deviasi standar untuk bulan ke $\mathrm{j}$ dan ke j-1. Nilai ti,j adalah variat acak yang mempunyai distribusi normal, tidak bergantung secara serial bernilai tengah nol dan berstandard deviasi satu dan $\bar{X}$ adalah debit rata-rata bulanan dari pengamatan. Koefisien Markov-Chain nilainya berkisar antara 0,2 - 0,3; dan umumnya digunakan nilai 0,25 .

\section{Metode Perbandingan DAS}

Limantara[2] menyebutkan jika pada suatu DAS tidak ada pengukuran data debit, maka bisa dipakai beberapa metode untuk mengestimasi data debit, salah satunya adalah metode perbandingan DAS. Jika dibandingkan dua DAS, maka persamaan metode perbandingan DAS adalah:

$$
Q_{m}=\frac{A_{m} \cdot Q_{o}}{A_{o}}
$$

dimana:

$\mathrm{Qm}=$ debit sungai pada lokasi perencanaan $\left(\mathrm{m}^{3} / \mathrm{dt}\right)$

Qo $\quad=$ debit sungai pada stasiun $\operatorname{AWLR}\left(\mathrm{m}^{3} / \mathrm{dt}\right)$

Ao $=$ luas DAS pada stasiun AWLR $\left(\mathrm{Km}^{2}\right)$

$\mathrm{Am} \quad=$ luas DAS pada lokasi perencanaan $\left(\mathrm{Km}^{2}\right)$

\section{Dimensi Groundsill}

Sosrodarsono dan Tominaga[3] menyebutkan bahwa groundsill bertujuan untuk mencegah gerusan dasar sungai dengan cara lebih melandaikan kemiringan dasarnya, guna mengurangi daya tarik aliran sungai. Groundsill dengan elevasi mercu yang terlalu tinggi akan menimbulkan berbagai masalah, antara lain dasar sungai di sebelah hulu groundsill akan naik dan air sungai dengan terjunan yang tinggi akan mengganggu stabilitas dasar sungai di sebelah hilir groundsill tersebut. Sedangkan groundsill yang terlalu rendah, pengamanan alur dan tebing sungai terhadap gerusan arus sungai tidak efektif, terutama saat terjadi banjir.

1. Tipe dan bentuk groundsill

Sosrodarsono dan Tominaga[3] menyebutkan terdapat dua tipe groundsill, yaitu groundsill datar (bed gindle work) dan groundsill pelimpah. Groundsill datar hampir tidak mempunyai terjunan dan elevasi mercu hampir sama dengan permukaan dasar sungai, dan berfungsi untuk menjaga agar permukaan dasar sungai tidak turun lagi. Sedangkan groundsill pelimpah mempunyai terjunan, dan tujuannya adalah untuk lebih melandaikan kemiringan dasar sungai akibat penurunan yang berlebihan.

2. Penentuan jarak dan tinggi groundsill

Apabila groundsill direncanakan untuk mengurangi kemiringan dasar sungai, khususnya pada sungai buatan (saluran banjir) atau pada sungai yang arusnya deras, tetapi tanggulnya rendah maka groundsill ganda dengan mercu-mercunya lebih tinggi dari dasar sungai dan dilengkapi dengan perkuatan tebing di kanan/kirinya. Apabila groundsill dibangun pada sungai secara menerus, maka lokasi, tinggi dan jumlah groundsill ditetapkan berdasarkan profil memanjang sungai.

Apabila groundsill dibangun pada sungai secara menerus, maka lokasi, tinggi dan jumlah groundsill ditetapkan berdasarkan profil memanjang sungai dengan menggunakan persamaan 3 untuk sungai sempit dan persamaan 4 untuk sungai lebar :

$$
\begin{aligned}
& \text { Untuk sungai yang sempit } \\
& l=(1 / n-1 / m) h=(1,5-2,0) \\
& \text { Untuk sungai yang lebar } \\
& l=(1,5-2,0) b \ldots \ldots \ldots \ldots \ldots \ldots \ldots \ldots \ldots \\
& \text { dimana: } \\
& 1 \quad=\text { jarak antar groundsill }(\mathrm{m}) \\
& \mathrm{h} \quad=\text { tinggi groundsill }(\mathrm{m})
\end{aligned}
$$$$
l=(1 / n-1 / m) h=(1,5-2,0) 1 / h \ldots .3)
$$ 


$$
\begin{array}{ll}
\mathrm{n} & =\text { kemiringan dasar sungai } \\
\mathrm{m} & =\text { tingkatan desain dasar sungai } \\
\mathrm{b} & =\text { lebar dasar sungai }(\mathrm{m})
\end{array}
$$

\section{Lantai lindung groundsill}

Menurut Sosrodarsono dan Tominaga[3] lantai lindung groundsill dikombinasikan dengan konsolidasi dasar sungai guna melindungi tubuh groundsill terhadap gerusan atau gejala piping. Lantai lindung dan dapat meredam energi yang terkandung dalam aliran air sungai sekaligus mengurangi kecepatan arus sungai di sebelah hilir ambang (groundsill).

Jika panjang yang diperlukan untuk peredam energi adalah $L_{l t}$, maka dapat dihitung dengan:

$$
L_{l t}=4,5 h_{2}
$$

dimana :

$$
L_{l t}=\text { Panjang lantai lindung }(\mathrm{m})
$$

\section{Kemiringan desain dasar sungai}

Menurut Sosrodarsono dan Tominaga[3] sebelum groundsill dibangun pada suatu sungai yang dasarnya turun secara terus menerus, maka tinggi dan jarak groundsill dapat ditetapkan secara perkiraan dan dihitung dengan metode coba-banding dan akhirnya akan diperoleh suatu kemiringan seimbang teoritis dasar sungai yang bersangkutan. Kemiringan desain dapat dihitung dengan persamaan

$$
m_{s}=\frac{1}{\left(\frac{1}{n_{s}}-\frac{l}{D}\right)}
$$

dimana :

$l=$ Jarak antar groundsill $(\mathrm{m})$

$D=$ Tinggi groundsill (m)

$n_{s}=$ Kemiringan dasar sungai

$m_{s}=$ Tingkatan desain dasar sungai

\section{Analisis stabilitas groundsill}

Analisis stabilitas groundsill bertujuan untuk mengetahui stabilitas groundsill apabila dihitung dengan berdasarkan standar teknis yang berlaku sebagai bentuk kontrol analisis perencanaan, sehingga dapat diketahui stabilitasnya.

1. Daya dukung tanah terhadap pondasi

Konstruksi bagian bangunan bawah tanah yang direncanakan untuk bangunan groundsill adalah pondasi dangkal. Untuk menghitung daya dukung yang ditimbulkan akibat berat bangunan digunakan persamaan :

$$
\sigma_{\mathrm{ytb}}=\frac{P_{u l t}}{B x L}
$$

dimana:

$$
\begin{gathered}
\sigma_{\text {ytb }}=\text { Tekanan oleh pondasi (ton } / \mathrm{m}^{2} \text { ) } \\
\mathrm{P}_{\mathrm{ult}} \quad=\text { Berat total bangunan (ton) }
\end{gathered}
$$

$$
\begin{array}{ll}
\mathrm{B} & =\text { Lebar pondasi }(\mathrm{m}) \\
\mathrm{L} & =\text { Panjang pondasi }(\mathrm{m})
\end{array}
$$

2. Gaya tekanan hidrostatis

Menurut Triatmodjo[4], tekanan ke atas pada dasar bendung di sebelah hulu adalah sama dengan tekanan hidrostatis pada dasar. Hitungan dilakukan untuk tiap $1 \mathrm{~m}$ panjang dengan persamaan sebagai berikut.

Tekanan hidrostatis pada dasar groundsill,

$\left.p_{B} \quad=H_{g} \gamma \ldots \ldots \ldots \ldots \ldots \ldots \ldots \ldots \ldots . \ldots . \ldots \ldots\right)$

Gaya tekanan hidrostatis pada sisi hulu groundsill,

$F_{x}=1 / 2 p_{B} H_{g} \times 1$

Gaya angkat pada dasar groundsill,

$F_{y}=1 / 2 p_{B} B$

dimana:

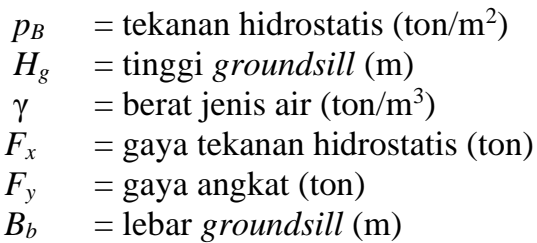

\section{Stabilitas terhadap guling dan geser}

Menurut Triatmodjo[4], untuk menyelidiki keamanan groundsill terhadap guling dan geser, perlu dibandingkan besar gaya geser dan momen guling terhadap gaya penahan geser dan momen penahan guling. Untuk menghitung tahanan geser digunakan persamaan:

$$
T \quad=\left(\mathrm{W}-F_{y}\right) f
$$

dimana:

$$
\begin{array}{ll}
T & =\text { tahanan geser groundsill (ton) } \\
W & =\text { berat bangunan (ton) } \\
f & =\text { Nilai Koefisiet Geser }
\end{array}
$$

Menurut Triatmodjo[4] untuk mendapatkan konstruksi yang aman terhadap gaya geser maka nilai $T>F_{x}$ dan untuk mendapatkan konstruksi yang aman terhadap momen guling maka nilai $M_{P G A}>M_{P A}$. Untuk menghitung momen penggulingan digunakan persamaan:

$$
M_{P A}=1 / 3 F_{x} H+2 / 3 F_{y} B_{b}
$$

Untuk menghitung momen penahan guling digunakan persamaan :

$$
M_{P G A}=W L_{x}
$$

dimana :

$$
\begin{array}{ll}
M_{P A} & =\text { momen penggulingan (tonm) } \\
M_{P G A} & =\text { momen penahan guling (tonm) } \\
L_{x} & =\text { jarak titik berat bangunan (m) }
\end{array}
$$

4. Analisis piping.

Menurut Sosrodarsono dan Tominaga[3] tingkat keamanan terhadap piping dengan nilai banding rayapan (creep ratio), jika 
angka $\mathrm{C}_{\mathrm{w}}=\mathrm{L}_{\mathrm{w}} / \mathrm{H}_{\mathrm{w}}$ lebih besar dari angka-angka seperti yang tertera pada Tabel 2.3.

$$
\begin{aligned}
& L_{w}=l_{1}+h_{1}+l_{2}+h_{2}+l_{3} \\
& C_{w}=L_{w} / H_{w}
\end{aligned}
$$

dimana :

$L_{w}=$ Panjang lintasan aliran air rembesan $(\mathrm{m})$

\section{Metode Perencanaan}

Lokasi studi untuk perencanaan bangunan groundsill dalam rangka untuk pengaturan sungai adalah pada salah satu anak sungai Krueng Aceh di bagian hulu, yaitu sungai Krueng Jantho, yang terletak di Desa Alue Gintung Kecamatan Seulimuem Kabupaten Aceh Besar dengan panjang sungai yang mencakup dalam kajian adalah $4400 \mathrm{~m}$.. Lokasi ini dipilih menjadi rencana kajian dikarenakan pada bagian sungai tersebut terdapat Jembatan Alue Gintung, dimana di bagian hulu dan hilir jembatan adanya kegiatan pengambilan material sungai yang cukup besar.

Sebagian besar data yang digunakan dalam studi ini merupakan data sekunder, yang didapatkan dari instansi terkait, khususnya Balai Wilayah Sungai Sumatera I Aceh. Kebutuhan data dalam studi ini adalah peta Daerah Aliran Sungai, peta topografi sungai, gambar penampang sungai, data debit sungai, dan data mekanika tanah.

Berdasarkan metode perbandingan luas antara DAS pos AWLR dan DAS Krueng Jantho pada lokasi studi, maka dapat diperkirakan debit harian maksimum tahunan untuk sungai Krueng Jantho. Luas DAS Krueng Aceh pada pos AWLR adalah 471,60 $\mathrm{Km}^{2}$ (sesuai publikasi data dari BWS Sumatera I) sedangkan luas DAS Krueng Jantho pada lokasi studi ini sesuai dengan analisis dan penggambaran menggunakan GIS adalah 386,20 $\mathrm{Km}^{2}$.

Tahapan perencanaan groundsill:

a. Pemilihan jenis groundsill

Jenis groundsill yang dipilih dalam perencanaan ini adalah groundsill datar konstruksi susunan batu atau pasangan bronjong batu dan menggunakan pondasi beton.

\section{b. Penentuan lokasi groundsill}

Bangunan groundsill direncanakan pada lokasi di sekitar jembatan Alue Gintung, baik pada bagian hulu atau hilir jembatan. Penempatan bangunan groundsill direncanakan sebanyak 5 unit yaitu pada JS 02, JS 07, JS 11, JS 14, Dan JS 17, sesuai dengan kemiringan dasar sungai.

\section{c. Formasi groundsill}

Pada perencanaan konstruksi bangunan groundsill, formasi groundsill dibuat lurus melintang sungai, atau tegak lurus terhadap arah aliran. Bangunan groundsill_diletakkan secara seri, dengan jarak bervariasi.

\section{d. Kemiringan desain dasar sungai $\left(m_{s}\right)$}

Perhitungan kemiringan dasar bertujuan untuk mengetahui seberapa besar kemiringan sungai pada kondisi eksisting sebelum direncanakan groundsill, dan kemiringan dasar sungai setelah adanya groundsill. Apabila kemiringan dasar sungai setelah adanya bangunan groundsill masih curam, maka direncanakan lebih dari satu bangunan.

\section{e. Tinggi groundsill $(D)$}

Tinggi groundsill dihitung dengan metode coba banding. Selanjutnya berdasarkan tinggi groundsill dapat dihitung panjang lantai lindung groundsill.

\section{f. Lantai lindung groundsill $\left(L_{l t}\right)$}

Lantai lindung groundsill direncanakan pada sisi hilir yang berfungsi untuk meredam energi sungai yang melewati mercu groundsill. Lantai lindung groundsill direncanakan dengan menggunakan susunan batu atau pasangan bronjong batu berlapis.

\section{g. Ukuran batu groundsill $\left(d_{m}\right)$}

Ukuran batu yang dipakai pada konstruksi groundsill menyesuaikan dengan perencanaan sebelumnya, atau menggunakan pasangan bronjong.

Analisis stabilitas groundsill:

a. Daya dukung tanah terhadap pondasi

Perhitungan daya dukung tanah terhadap pondasi dimulai dengan menghitung berat bangunan groundsill dan berat air yang melalui groundsill. Selanjutnya dihitung tekanan yang ditimbulkan oleh pondasi dan daya dukung tanah terhadap pondasi. Konstruksi groundsill dinyatakan aman apabila nilai Safety Factor $(S F)$ lebih besar dari 1,3.

b. Gaya tekanan hidrostatis $\left(F_{x}\right)$

Dalam merencanakan konstruksi groundsill perlu diperhitungkan gaya tekanan hidrostatis yang bekerja pada tubuh groundsill, perhitungan gaya hidrostatis meliputi gaya tekanan hidrostatis pada sisi hulu groundsill dan gaya angkat pada dasar groundsill.

c. Stabilitas terhadap guling $\left(M_{P A}\right)$ dan geser

Untuk mendapatkan konstruksi groundsill yang stabil perlu diselidiki stabilitas terhadap momen guling dan gaya geser. Untuk mendapatkan konstruksi groundsill yang aman terhadap momen guling $\left(M_{P A}\right)$ maka momen penahan guling $\left(M_{P G A}\right)$ harus lebih besar dari momen guling. Dan untuk mendapatkan konstruksi groundsill yang aman terhadap gaya geser $\left(F_{x}\right)$ maka gaya tahanan geser $(T)$ harus lebih besar daripada gaya tekanan hidrostatis pada sisi hulu bendung.

d. Mempelajari gejala piping.

Pada perencanaan groundsill, perlu diperhitungkan keamanan terhadap gejala piping yang terjadi akibat adanya rembesan air dibawah pondasi groundsill. Perhitungan keamanan terhadap 
gejala piping dilakukan dengan terlebih dahulu menghitung panjang lintasan aliran rembesan air $\left(L_{w}\right)$. Selanjutnya dihitung nilai banding rayapan $\left(C_{w}\right)$. Untuk mendapatkan konstruksi groundsill yang aman terhadap gejala piping maka nilai banding rayapan harus lebih besar daripada nilai yang tertera pada tabel harga kritis.

\section{Hasil dan pembahasan}

\section{Pembangkitan debit metode Markov Chain}

Data debit yang digunakan untuk pembangkitan debit adalah data debit harian maksimum bulanan tahun 1972 sampai tahun 1980. Berdasarkan nilai rata-rata dan standar deviasi selanjutnya dilakukan pembangkitan data untuk tahun 1987, 1989, 1990, dan tahun 1998 sampai tahun 2018. Sedangkan untuk tahun 1981 sampai 1997 tidak dilakukan pembangkitan data, karena data debit maksimum telah tersedia.

Data yang digunakan untuk analisis debit banjir rencana dalam studi ini adalah data debit harian maksimum tahunan pada site perencanaan di Krueng Jantho. Berdasarkan analisa debit banjir rencana, data debit yang dibutuhkan berbeda dengan posisi stasiun AWLR, maka di gunakan metode perbandingan DAS

\section{Analisis Debit Banjir Rencana}

Menurut Triatmodjo[5] hasil Perhitungan parameter statistik dengan menggunakan data debit harian maksimum tahunan adalah mean $(\mathrm{Qr})=$ $140,36 \mathrm{~mm}$, standard deviation $(\mathrm{S})=55,28 \mathrm{~mm}$, coefficient of variation $(\mathrm{Cv})=0,39$, coefficient of skewness $(\mathrm{Cs})=0,625$ dan coeffecient of kurtosis $(\mathrm{Ck})=0,91$.

Analisis debit banjir rencana menggunakan metode distribusi Log Pearson tipe III. Debit banjir rencana dihitung untuk periode ulang 2 tahun, 5 tahun, 10 tahun, 25 tahun dan 50 tahun. Hasil perhitungan debit banjir rencana sungai Krueng Jantho disajikan pada Tabel 1.

Tabel 1 Debit Banjir Rencana Sungai Krueng Jantho

\begin{tabular}{cc}
\hline $\begin{array}{c}\text { Periode ulang }(\mathbf{T}) \\
\text { tahun }\end{array}$ & $\begin{array}{c}\text { Debit Rencana }\left(\mathbf{Q}_{\mathbf{T}}\right) \\
\left(\mathbf{m}^{\mathbf{3}} / \mathbf{d t}\right)\end{array}$ \\
\hline 2 & 133.91 \\
\hline 5 & 185.52 \\
\hline 10 & 215.47 \\
\hline 25 & 248.98 \\
\hline 50 & 274.71 \\
\hline
\end{tabular}

\section{Rating Curve}

Penggambaran rating curve didasarkan pada nilai debit (Q) dan tinggi muka air $(\mathrm{H})$. Gambar
1 memperlihatkan rating curve yang diperoleh dengan menggunakan metode Strickler. Berdasarkan potongan melintang sungai JS02, didapatkan lebar dasar sungai adalah $52 \mathrm{~m}$, kemiringan tebing sungai adalah 1:8, koefisien Strickler adalah 25, kemiringan dasar sungai adalah 0.0030, dan elevasi dasar sungai adalah $+42.3 \mathrm{~m}$. Tinggi muka air pada penampang JS02 yang diperoleh untuk debit maksimum rata-rata sebesar $140.36 \mathrm{~m}^{3} / \mathrm{dt}$ adalah $1.43 \mathrm{~m}$. sedangkat untuk debit banjir rencana Q25 tahun sebesar 248.98 m³/dt didapatkan tinggi muka air adalah $1.98 \mathrm{~m}$.

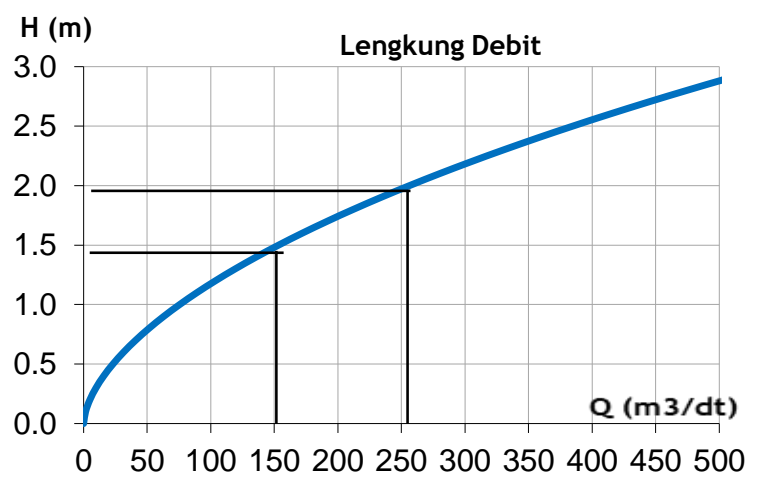

Gambar 1 Rating Curve pada JS 2

\section{Perencanaan Groundsill}

Bangunan groundsill yang dipilih dalam perencanaan ini adalah groundsill tipe datar dengan konstruksi pasangan bronjong dan menggunakan pondasi pasangan batu. Tujuan perencanaan groundsill tipe datar ini adalah untuk mencegah gerusan dasar sungai dengan cara lebih melandaikan kemiringan dasarnya sehingga mengurangi gaya tarik alirannya.

Lokasi bangunan groundsill dalam studi ini direncanakan berdasarkan kondisi topografi, morfologi dan hidrometri sungai Krueng Jantho. Konstruksi groundsill direncanakan sebanyak lima bangunan yang diletakan melintang sungai Krueng Jantho pada penampang JS.02, JS.07, JS.11, JS.14, dan JS.17. Dalam perencanaan ini, jarak antar groundsill direncanakan berdasarkan kondisi morfologi sungai, lokasi galian $\mathrm{C}$ dan posisi jembatan Alue Gintung. Lebar sungai rata-rata pada lokasi perencanaan adalah 83,70 meter, dan kemiringan rata-rata dasar sungai 0,0033 . Kemiringan sungai eksisting pada lokasi perencanaan termasuk cukup curam. Berdasarkan rerata lebar sungai tersebut maka direncanakan lebar dasar groundsill adalah 80,00 meter, dengan lebar atas adalah 84,00 meter.

Perencanaan formasi atau tata letak groundsill adalah lurus melintang sungai, atau tegak lurus terhadap arah aliran. Bangunan groundsill direncanakan sebanyak lima unit yang diletakkan secara seri, dengan jarak bervariasi. Kemiringan sisi hulu groundsill direncanakan tegak, karena pada sisi 
ini akan menjadi landai dengan sendirinya akibat dari angkutan dan penumpukan sedimen setelah adanya groundsill nantinya. Sedangkan kemiringan sisi hilir direncanakan lebih landai yaitu sebesar 1:2, dengan tujuan untuk meredam energi air yang melewati mercu groundsill sehingga mengurangi gerusan dasar sungai di hilir bangunan groundsill. Mercu groundsill direncanakan datar dengan tebal 4 meter.

Tinggi groundsill direncanakan dengan metode coba banding dengan mempertimbangkan kemiringan dasar sungai eksisting dan kemiringan desain. Berdasarkan hasil perhitungan, tinggi seluruh groundsill direncanakan sebesar 1 meter. Tinggi groundsill direncanakan tidak terlalu tinggi karena kemiringan dasar sungai awal tidak terlalu curam dan tujuan utama dari perencanaan groundsill untuk memperbaiki keadaan dasar sungai.

Lantai lindung groundsill direncanakan pada sungai sisi hulu dan hilir pondasi groundsill, yang berfungsi untuk meredam energi sungai yang melewati mercu groundsill. Lantai lindung groundsill direncanakan dengan menggunakan matras bronjong batu berlapis hingga setebal 0,50 meter. Berdasarkan hasil perhitungan, panjang lantai lindung hulu direncanakan 2,00 meter dan panjang lantai lindung hilir direncanakan sepanjang 4,00 meter.

Kemiringan desain dasar sungai dihitung untuk mengetahui perubahan kemiringan dasar sungai yang terjadi karena adanya groundsill. Berdasarkan perencanaan kemiringan desain dasar sungai adalah 0,0005, minimum debit rerata adalah $1.23 \mathrm{~m} / \mathrm{d}$ dan kecepatan maksimumnya $2.23 \mathrm{~m} / \mathrm{d}$ pada debit banjir periode ulang 25 tahun sehingga perencanaan groundsill dinyatakan aman jika dilihat pada kecepatan kritis.

Ukuran diameter batu pengisi bronjong groundsill ditentukan sebesar 10,16 - 20,32 cm. Untuk pengamanan groundsill digunakan turap dengan material kayu dengan panjang $3 \mathrm{~m}$, diameter $10 \mathrm{~cm}$ yang dipasang pada setiap bronjong. Desain bangunan groundsill disajikan pada Gambar 2 berikut.

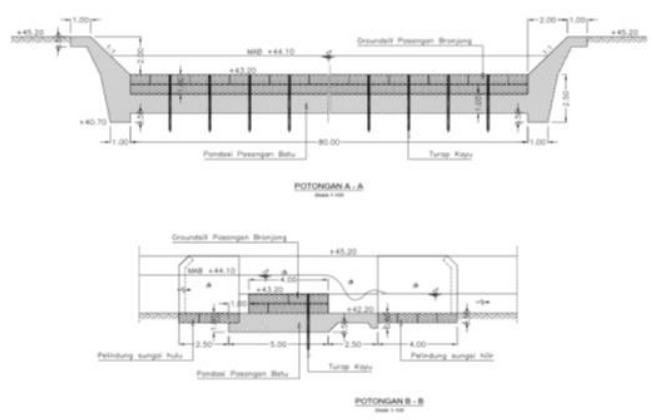

Gambar 2 Rencana Dimensi Groundsill sungai Krueng Jantho

\section{Analisa Stabilitas Groundsill}

Perhitungan analisa stabilitas meliputi :

Berdasarkan perhitungan yang telah dilakukan pada keadaan tinggi air normal, tekanan yang ditimbulkan oleh pondasi ( $\left.\sigma_{\mathrm{ytb}}\right)$ groundsill adalah sebesar $4,28 \mathrm{~kg} / \mathrm{cm}^{2}$, tekanan tanah $\left(\mathrm{q}_{\mathrm{c}}\right)$ sebesar 27,68 kg/cm ${ }^{2}$ dan daya dukung tanah (qult) sebesar $7,55 \mathrm{~kg} / \mathrm{cm}^{2}$. Nilai safety factor (SF) yang didapat sebesar 1,77 melebihi nilai (SF) aman sebesar 1,3 sehingga dinyatakan tanah pada konstruksi groundsill mampu menahan beban groundsill pada keadaan tinggi air normal. Untuk perhitungan yang telah dilakukan pada keadaan tinggi air banjir periode ulang 25 tahun, tekanan yang ditimbulkan oleh pondasi $\left(\sigma_{\mathrm{ytb}}\right)$ groundsill adalah sebesar $5,35 \mathrm{~kg} / \mathrm{cm}^{2}$, tekanan tanah $\left(\mathrm{q}_{\mathrm{c}}\right)$ sebesar $27,68 \mathrm{~kg} / \mathrm{cm}^{2}$ dan daya dukung tanah (qult) sebesar $7,55 \mathrm{~kg} / \mathrm{cm}^{2}$.

Berdasarkan perhitungan yang telah dilakukan pada groundsill, gaya tekanan hidrostatis pada dasar $\left(p_{B}\right)$ groundsill yang ditimbulkan sebesar $1.96 \mathrm{ton} / \mathrm{m}^{2}$, gaya tekanan hidrostatis pada sisi hulu $(F x)$ groundsill sebesar 1,93 ton dan gaya angkat pada dasar (Fy) groundsill sebesar 8,44 ton.

Konstruksi groundsill dinyatakan aman terhadap guling apabila nilai momen guling $\left(M_{P A}\right)$ lebih kecil daripada nilai momen penahan guling $\left(M_{P G A}\right)$ dan dinyatakan aman terhadap gaya geser apabila nilai gaya hidrostatis pada sisi hulu $\left(F_{y}\right)$ groundsill lebih kecil daripada nilai tahanan geser $(T)$. Berdasarkan perhitungan yang telah dilakukan pada groundsill, gaya tahanan geser $(T)$ pada groundsill sebesar 15 ton, momen guling $\left(M_{P A}\right)$ sebesar 43,44 tonm dan momen penahan guling $\left(M_{P G A}\right)$ sebesar 103,01 tonm.

Berdasarkan perhitungan yang telah dilakukan pada groundsill, panjang lintasan aliran air rembesan $\left(L_{w}\right)$ adalah sebesar 9,80 meter dan beda tinggi air antara hulu dan hilir $\left(H_{w}\right)$ adalah sebesar $1,04 \mathrm{~m}$ sehingga didapai nilai banding rayapan $\left(C_{w}\right)$ sebesar 9,38. Untuk Sungai Krueng Jantho daerah Desa Alue Gintung mengandung sedimen berupa pasir kasar, nilai banding rayapan $\left(C_{w}\right)$ kritis berdasarkan Tabel harga kritis sebesar 5 lebih kecil dari nilai banding rayapan $\left(C_{w}\right)$ hitung sebesar 9,38 sehingga groundsill ini dinyatakan aman terhadap gejala piping.

\section{Kesimpulan dan Saran}

Dari hasil penelitian dapat diambil kesimpulan sebagai berikut :

1. Debit banjir rencana dengan metode distribusi Log Pearson III, didapatkan untuk periode ulang 25 tahun $248,98 \mathrm{~m}^{3} / \mathrm{dt}$, dan periode ulang 50 tahun $274,71 \mathrm{~m}^{3} / \mathrm{dt}$. 
2. Bangunan groundsill yang direncanakan adalah tipe pelimpah dengan konstruksi pasangan bronjong batu dan mengunakan pondasi pasangan batu. Bangunan groundsill direncanakan sebanyak lima unit yang diletakkan melintang sungai Krueng Jantho pada penampang JS.02, JS.07, JS.11, JS.14, dan JS.17.

3. Dimensi groundsill yang direncanakan adalah, tinggi ambang 1,00 meter, tebal mercu 4,00 meter, lebar dasar 80,00 meter, sedangkan lebar pondasi 7,50 meter. Panjang lantai lindung groundsill direncanakan pada bagian hulu 2,00 meter, dan bagian hilir sepanjang 4,00 meter, dengan konstruksi pasangan bronjong.

4. Perubahan kemiringan dasar sungai rerata yang terjadi dengan adanya bangunan groundsill di lokasi perencanaan adalah dari kemiringan 0,0033 menjadi 0,0005 .

5. Tanah pondasi pada lokasi perencanaan groundsill mampu untuk menahan gaya berat seluruh konstruksi groundsill. Seluruh konstruksi groundsill aman terhadap gaya geser, momen guling dan gejala piping.

Sesuai perhitungan dan pembahasan, maka dapat diambil beberapa kesimpulan dan saran berikut.

1. Perlu dilakukan pemodelan fisik ataupun numerik untuk mengetahui seberapa efektif bangunan pengaman dasar sungai ini bekerja.

2. Dalam studi perencanaan bangunan pengaturan sungai, sebaiknya penerapannya bukan hanya diterapkan pada satu daerah atau kawasan, perlu dilakukan studi perencanaan pada lokasi lain di sungai Krueng Jantho yang rawan terjadi gerusan terhadap tebing dengan konstruksi yang sama ataupun berbeda.

3. Dalam penerapan perencanaan dan pelaksanaan bangunan pengaturan sungai secara nyata di lapangan sangat diperlukan kesadaran, pemahaman dan partisipasi masyarakat dan pemerintah.

\section{Daftar Pustaka}

[1] Soewarno, Aplikasi Metode Statistika untuk Analisis Data Hidrologi, Graha Ilmu, Yogyakarta, 2010.

[2] Limantara, L. M., Hidrologi Praktis, CV. Lubuk Agung, Bandung, 2010.

[3] Sosrodarsono, S., dan Tominaga, M., Perbaikan dan Pengaturan Sungai, Pradnya Paramita, Jakarta, 2008.

[4] Triatmodjo, B., Hidraulika I, Beta Offset, Yogyakarta. 2003.

[5] Triatmodjo, B., Hidrologi Terapan, Beta Offset, Yogyakarta, 2009. 